\title{
Auto-Dissemination of Beauveria bassiana in Controlling Coffee Berry Borer
}

\author{
Endang Sulistyowati ${ }^{1 *}$, Dwi Suci Rahayu ${ }^{1)}$, Merle Shepard ${ }^{2)}$, and Gerry Carner ${ }^{2)}$ \\ ${ }^{1)}$ Indonesian Coffee and Cocoa Research Institute, J1. PB Sudirman No. 90, Jember, Indonesia \\ ${ }^{2}$ Clemson University, 101 Caulhoun Dr, Clemson, South Carolina, USA \\ ${ }^{*}$ Corresponding Author : liessuryo@yahoo.co.id \\ Received: 15 September 2016/ Accepted: 3 May 2017
}

\begin{abstract}
Coffee berry borer (CBB), Hypothenemus hampei Ferr. (Coleoptera, Scolytidae) is generally controlled by applying integrated pest management, particularly through sanitation and using biological agents. Beauveria bassiana is wellknown as an entomopathogenic fungus, which has been proven to be the most effective and prospective agent that could be developed to control CBB. Dissemination of microbial biocontrol agents via insect or predators may has advantages for safe spore dispersal to targeted pests with the added benefit of predation. The research with aim to determine if spores of $B$. bassiana can be picked up by CBB from disseminated containers had been conducted at Plant Protection Laboratory and Kaliwining Experimental Station of Indonesian Coffee and Cocoa Research Institute. Ten infected coffee berries and ten CBB adults were sprayed with various concentration of B. bassiana suspension, and then infested them in 10 healthy berries in petridish. The same trials was conducted in the field, by infested them to healthy berries on coffee branches. Observation was done on the percentage of infected berries and number of CBB infected by $B$. bassiana inside the berries. The results showed that spores of $B$. bassiana could be picked up by $\mathrm{CBB}$ from disseminated containers, although it was very low $(2.5 \%)$. B. bassiana was not effective in suppressing $\mathrm{CBB}$ infestation by auto-dissemination, therefore to improve the effectiveness of B. bassiana in controlling $\mathrm{CBB}$, it was advised to re-spray at least 3 times in every cropping season, especially at the flying time of CBB around 2 P.M.
\end{abstract}

Keywords: coffee berry borer, Hypothenemus hampei, Beauveria bassiana, auto-dessimination

\section{INTRODUCTION}

Coffee berry borer (CBB), Hypothenemus hampei Ferr. (Coleoptera, Scolytidae) is the major constraint on coffee production in most parts of coffee growing region. Endemic in Central Africa, it has now spread to most of coffee growing regions (Baker cit. Vega, 2002). The coffee berry borer entered Indonesia in 1909 in Central Java, and then in 1918 it had been found to spread in East Java and other coffee regions (Cramer, 1957) and Brazil in 1913 (Neiva cit. Ceja-Navarro, 2015) and now presents in most coffee-producing countries. The female of coffee berry borers are minute bark beetles ( $c a .2 \mathrm{~mm}$ long) that bore a hole in the coffee berry and build galleries within the coffee seed, where they deposit their eggs. Larvae feed inside the seed, causing significant losses both in quality and yields. In Brazil the losses alone was estimated at \$285-315 million per year 
(Oliveira et al., 2013), making the insect is the most devastating pest on coffee worldwide.

This cryptic life cycle inside the berry makes problem on insect control. This small scolytid beetle attacks the coffee berries directly, preferring the near mature berries but will also attack younger ones. Adults feed on the berry pulp and young larvae develop inside berries, making them safe from most natural enemies. Female adults bore a hole in the coffee berry and deposit their eggs, larvae feed on the endosperm, reducing its quality and possibly causing abscission of the berry (Le Pelley, 1968). The attack of this pest may reduce quality and quantity of coffee beans. The reduction varies and it can reach more than $50 \%$.

CBB is generally controlled by applying integrated pest management, particularly sanitation, management of shade tree, and using biological agents or attractant (Junianto $\&$ Sulistyowati, 1994). Several parasitoids have been released such as Cephalonomia stephanoderis. Although a few parasitoids have become established, these do not seem to make a significant impact on the coffee berry borer populations in most areas.

Beauveria bassiana is well-known as an entomopathogenic fungus, with worldwide distribution. Although the use of insect pathogens has promise, there is some concern about potential nontarget effects (Hajek \& Goettel, 2000). For example, there are reports that B. bassiana kill nontarget beneficial insects such as lady beetles (James \& Lighthart, 1994). Indonesian Coffee and Cocoa Research Institute (ICCRI) have a strains of B. bassiana proven to be most effective and prospective agent controlling $\mathrm{CBB}$, namely $B$. bassiana $\mathrm{Bb}-715$ isolate. Application of B. bassiana Bb-715 suspension in $100 \mathrm{~g}$ dry spores/ha in three or four times every crop season, could suppress CBB infestation up to $69.1 \%$ (Sulistyowati et al., 2014). However, the success of this method varies considerably. Their effectiveness and persistence in the field may be increased by auto-dissemination devices, which have been proved effective in the control of various groups of insects (Vega et al., 1995). The success of the auto-infection system depends on the virulence and persistence of the entomopathogen strain, and the efficacy of the autodisseminator in attracting the target insect and transmitting inoculum to it (Kreutz et al. cit. Francardi et al., 2013)

When applied by conventional means using spraying, insect pathogens such as B. bassiana incur the same costs as chemical insecticides, which may make them not economical for use on low economic commodity value. Therefore, development of a low-cost autodissemination technique for entomopathogenic fungi where the insect can spread the fungus via horizontal transmission to conspecifics (e.g. during mating) is needed. There is no information wether many CBB in the field can disseminate their spores to the others target. This research activity observed autodissemination of the most efficacious strain of $B$. bassiana by $\mathrm{CBB}$ insect, in controlling $\mathrm{CBB}$.

\section{MATERIALS AND METHODS}

The research was conducted in the Laboratory of Plant Protection and at the coffee plantation of Kaliwining Experimental Station, ICCRI. The trial was arranged in randomized complete block design, with four level spore concentrations of $B$. bassiana and four replications.

For laboratory trial, the infected berries and healthy berries were collected from coffee farms. CBB adults used in the research were collected from CBB pupae that picked up from infected berries by dissecting the berries. Ten infected berries contained of CBB insects 
and ten CBB adults were sprayed by suspension of B. bassiana in 0 (Control); $2 \mathrm{~g}, 4 \mathrm{~g}$ and $6 \mathrm{~g}$ dry spores/10 L water concentrations. Infected berries and CBB insects that had been sprayed by $B$. bassiana suspension, were placed separately into petridishes (diameter $9 \mathrm{~cm}$ ) that already contained 10 healthy coffee berries. Observation was conducted four weeks after treatment on number of healthy berries, infested by CBB and number of CBB stadium (eggs, larvae, prapupae, pupae and adult) infected by $B$. bassiana inside the berries using dissection method of the berries.

In vitro test with the same purpose was conducted in coffee plantation of Kaliwining Experimental Station of ICCRI. One branch of coffee which contained of healthy berries was caged and infested by ten adults of CBB which had been sprayed by suspension of B. bassiana in $0,2,4$, and $6 \mathrm{~g}$ dry spores/ $10 \mathrm{~L}$ concentrations. Another treatment was the infected coffee berries by CBB was sprayed by $B$. bassiana suspension in same concentrate. After sprayed, the infected berries was infested in the coffee branch contained of healthy berries in the cage. Daily observation were conducted on number of infected berries by $\mathrm{CBB}$, mortality of $\mathrm{CBB}$ and number of CBB infection by B. bassiana. Dead CBB was put in petridish and added with wet cotton to stimulate sporulation. Four weeks after treatment, CBB population inside the coffee berries (both infected by $B$. bassiana or healthy) was observed by dissecting the coffee berries.

\section{RESULTS AND DISCUSSION}

\section{Laboratory Test}

Based on statistical analyses, there was no significant difference between concentration treatments of B. bassiana on CBB infestation, number of $\mathrm{CBB}$ killed, and number of CBB parasitized by B. bassiana, but there was significantly different on number of living CBB. In Table 1, it appeared that the adult population living $\mathrm{CBB}$ was high in control followed by $B$. bassiana treatment, but not CBB parazitized by entomopatogen fungus B. bassiana.

Observation result on the population of CBB inside coffee berries, showed that some of CBB adults were infected by $B$. bassiana. Number of CBB parasitized inside the berries was very low, between $0.09-0.1 \mathrm{CBB} /$ berry. It means that $B$. bassiana can disseminate their spores by themselves. The lowest dissemination of $B$. bassiana spores maybe affected by the behaviour of CBB.

The average number of eggs, larvae, pupae and prapupae stadia of CBB in the treatment of $B$. bassiana $0-6 \mathrm{~g} / 10 \mathrm{~L}$ did not differ significantly, though there was a tendency that the average number of eggs, larvae, pupae and prapupae stadia of CBB on treatment of $B$. bassiana $0 \mathrm{~g} / 10 \mathrm{~L}$ was the highest while at the treatment of B. bassiana $6 \mathrm{~g} /$ $10 \mathrm{~L}$ was the lowest (Table 2). On the parameter of percentage of CBB infected by B. bassiana also showed the same results, because the coffee fruits sprayed was those infected by

Table 1. Number of CBB adults inside coffee berries on various concentrations of B. bassiana

\begin{tabular}{cccc}
\hline \begin{tabular}{c} 
B. $\begin{array}{c}\text { bassiana } \\
(\mathrm{g} / 10 \mathrm{~L})\end{array}$ \\
\cline { 2 - 4 }
\end{tabular} & \multicolumn{4}{c}{ Number of CBB } \\
\hline 0 & $9.57 \pm 2.67 \mathrm{a}$ & Dead & Parasitized \\
2 & $2.15 \pm 0.81 \mathrm{c}$ & $0.05 \pm 0.10 \mathrm{a}$ & $0.00 \pm \mathrm{a}$ \\
4 & $4.65 \pm 1.71 \mathrm{~b}$ & $0.22 \pm 0.27 \mathrm{a}$ & $0.14 \pm 0.18 \mathrm{a}$ \\
6 & $4.63 \pm 2.24 \mathrm{~b}$ & $0.17 \pm 0.24 \mathrm{a}$ & $0.14 \pm 0.17 \mathrm{a}$ \\
\hline Note: & $0.10 \pm 0.13 \mathrm{a}$ & $0.09 \pm 0.12 \mathrm{a}$ \\
\hline
\end{tabular}




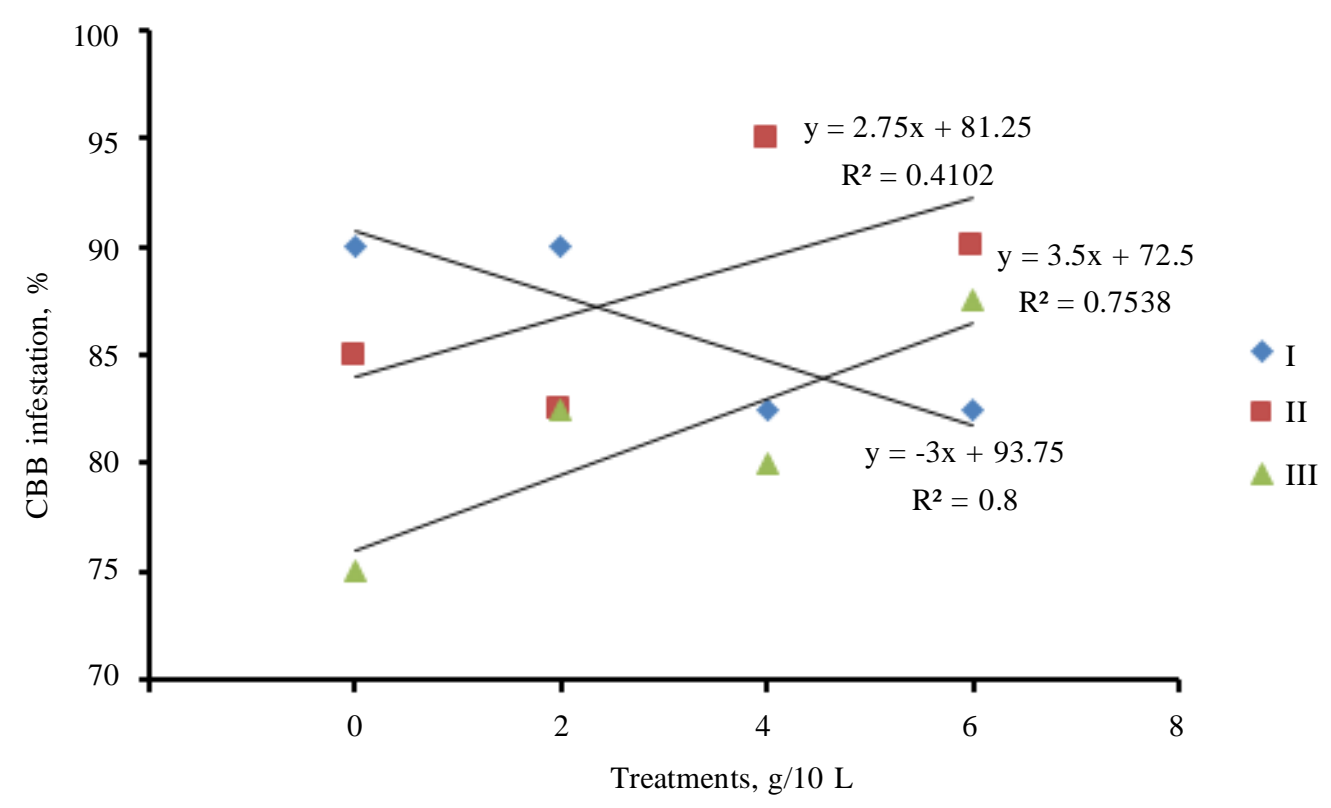

Figure 1. Percentage of $\mathrm{CBB}$ infestation on various concentration of B. bassiana

Table 2. CBB population (egg, larvae, prepupae and pupae) inside coffee berries, four week after treatment of B. bassiana

\begin{tabular}{ccccc}
\hline B. bassiana, (g/10 L) & Eggs & Larvae & Prapupae & Pupae \\
\hline 0 & $0.83 \mathrm{a}$ & $1.09 \mathrm{a}$ & $0.82 \mathrm{a}$ & $0.81 \mathrm{a}$ \\
2 & $0.17 \mathrm{a}$ & $1.14 \mathrm{a}$ & $0.44 \mathrm{a}$ & $1.13 \mathrm{a}$ \\
4 & $0.19 \mathrm{a}$ & $0.63 \mathrm{a}$ & $0.48 \mathrm{a}$ & $0.83 \mathrm{a}$ \\
6 & $0.08 \mathrm{a}$ & $0.63 \mathrm{a}$ & $0.18 \mathrm{a}$ & $0.78 \mathrm{a}$ \\
\hline
\end{tabular}

Note: $\quad$ Means values within the same column followed by the same letter are not significantly different $($ LSD test, $\mathrm{P}=0.05)$.

CBB, therefore it was suspected that $B$. bassiana could not enter into the fruits and infect the CBB adults as well as other CBB stadia. Therefore, $\mathrm{CBB}$ adults could fly and attack other healthy coffee fruits.

Referring the report of El-Sufty et al. (2011), a trap was designed to allow red palm weevil adults to pass through it so that they come out and contaminated with a high density of the fungus conidia for spreading them amongst the red palm weevil population in date palm plantations. In the last two months, mortality of adults caused by the fungus in the field population ranged $41.2-51.3 \%$ compared with $4.8-4.9 \%$ in control. Results showed that the trap was effective for spreading the fungus B. bassiana among Rhynchophorus ferrugineus population.

Observation results four weeks after treatment showed that percentage of CBB infestation and population were lower than treatment of $B$. bassiana suspension sprayed on infected berries. Number of CBB parasitized was higher, especially on high concentration of B. bassiana spores ( 4 and $6 \mathrm{~g} / 10 \mathrm{~L}$ ). Based on these results it can be concluded that for controlling $\mathrm{CBB}$, it must be ensured that the CBB adults carry B. bassiana spores, then spraying of $B$. bassiana suspension should be done at the time of the flight period of CBB. This can be proved by grow out CBB insects come out of infected fruit on certain 
media in order to observe stadia of CBB in insects due to B. bassiana infection. fruit, then counting living and non-living

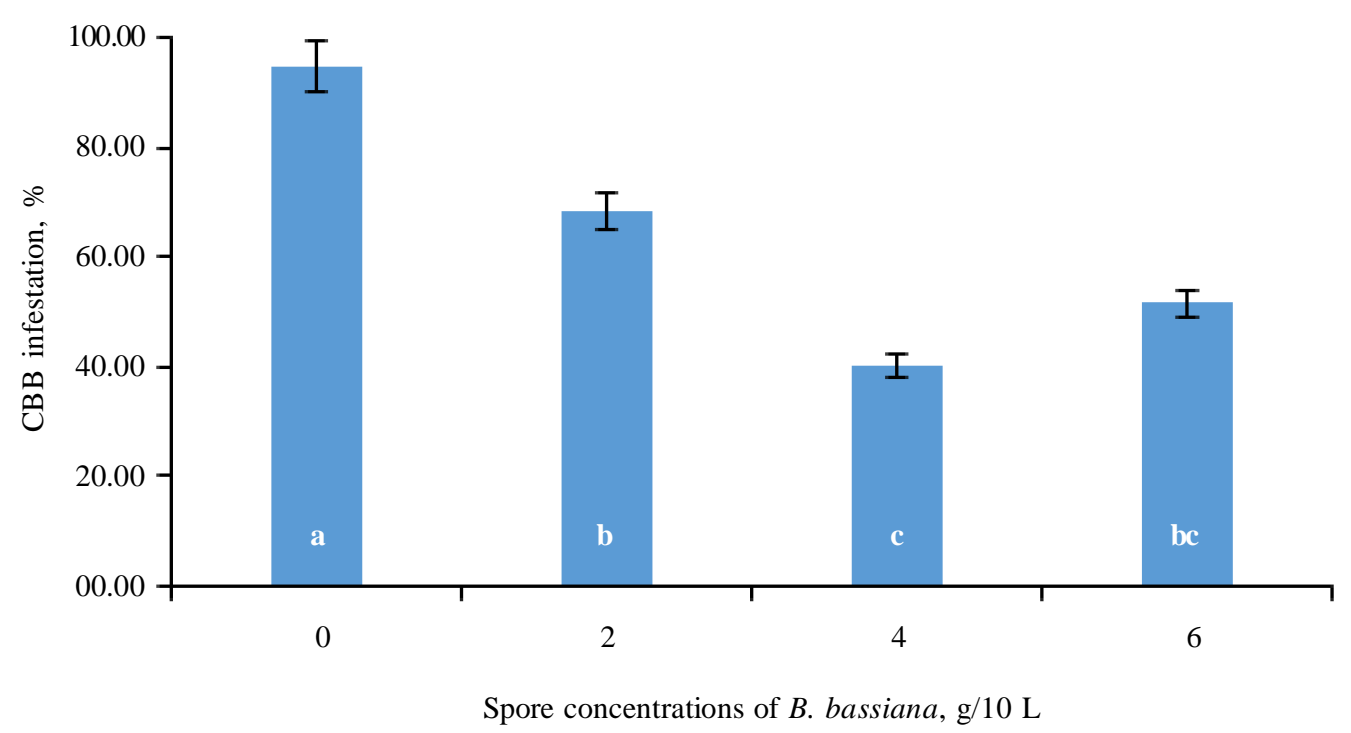

Figure 2. Percentage of CBB infestation on various concentrations of B. bassiana

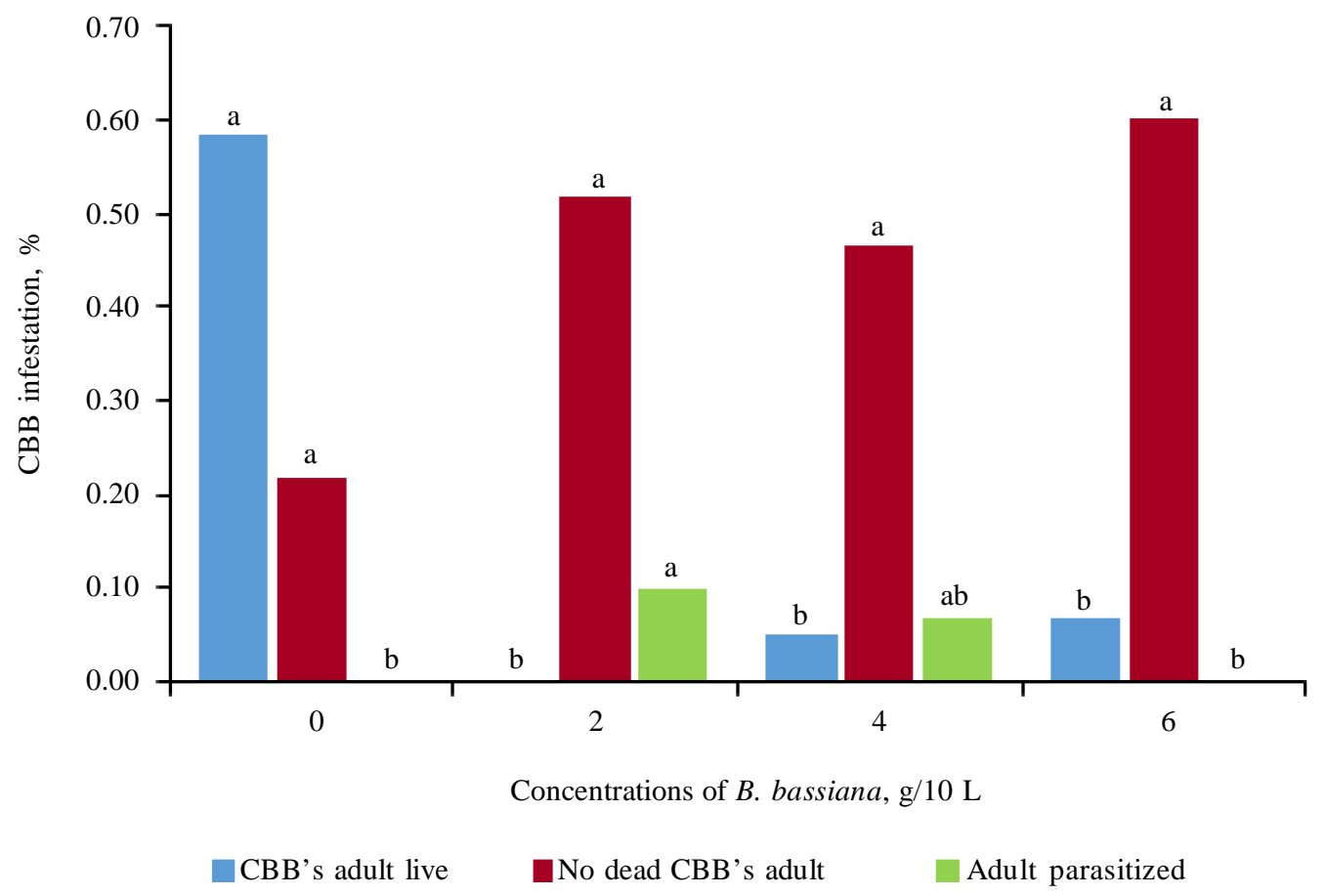

Figure 3. Number of CBB's adults inside coffee berry on various concentration of B. bassiana 
Based on the data analysis of CBB population in the coffee berries, it was known that there was a significant difference due to concentration treatments of $B$. bassiana on total population of CBB larvae, prepupae and pupae, but no significant difference on egg population. This was possibly that the CBB adults did not mate, as seen on $B$. bassiana 2-6 g/10 L treatment, there was no PBKo egg was laid. According to Seegers et al. (2008), pathogens can be spread by infected individual to other pathogen unifected individuals. Fungi can be transmitted horizontally at the time of mating. Anopheles gambiae males that had acquired fungal infection after mating indicated that passive transfer of the pathogen from infected females did occur, with mean male infection rates between $10.7 \pm 3.2 \%$ and $33.3 \pm 3.8 \%$, auto-dissemination of fungal inoculum between An. gambiae s.s mosquitoes during mating activity is possible under laboratory conditions (Scholte et al., 2004).

\section{Field Test}

Application of B. bassiana on CBB adults showed that there was no significant difference between the treatments. The lowest percentage of CBB attack (71.0\%) showed on $B$. bassiana concentration treatment of $6 \mathrm{~g}$ spore $/ 10 \mathrm{~L}$, while the highest of $\mathrm{CBB}$ attack $(88.8 \%)$ contained in the untreated (control). Although the results of the analysis were not significantly different, there was indication that higher concentration of $B$. bassiana produced a low percentage of CBB attack. According to Junianto \& Sulistyowati (2002), CBB control by spraying of $B$. bassiana in $0.05-0.2 \%$ concentration of spores caused CBB infected by B. bassiana between 37.8 to $42.4 \%$.

Table 3. CBB population (egg, larvae, prepupae and pupae) inside coffee berries four weeks after treatment of B. bassiana

\begin{tabular}{ccccc}
\hline \multirow{2}{*}{$\begin{array}{c}\text { B. bassiana } \\
(\mathrm{g} / 10 \mathrm{~L})\end{array}$} & \multicolumn{4}{c}{ Number of stages of CBB, H. Hampei inside the coffee berry } \\
\cline { 2 - 5 } & Eggs & Larvae & Prapupae & Pupae \\
\hline 0 & $0.23 \pm 0.41 \mathrm{a}$ & $2.35 \pm 1.85 \mathrm{a}$ & $0.78 \pm 0.56 \mathrm{a}$ & $1.25 \pm 0.54 \mathrm{a}$ \\
2 & $0.00 \pm 0.00 \mathrm{a}$ & $0.00 \pm 0.00 \mathrm{~b}$ & $0.00 \pm 0.00 \mathrm{~b}$ & $0.07 \pm 0.16 \mathrm{~b}$ \\
4 & $0.00 \pm 0.00 \mathrm{a}$ & $0.00 \pm 0.00 \mathrm{~b}$ & $0.00 \pm 0.00 \mathrm{~b}$ & $0.00 \pm 0.00 \mathrm{~b}$ \\
6 & $0.00 \pm 0.00 \mathrm{a}$ & $0.02 \pm 0.04 \mathrm{~b}$ & $0.07 \pm 0.16 \mathrm{~b}$ & $0.10 \pm 0.24 \mathrm{~b}$ \\
\hline
\end{tabular}

Notes: Means values within the same column followed by the same letter are not significantly different (LSD test, $\mathrm{P}=0.05)$ Means $\pm \mathrm{SD}$

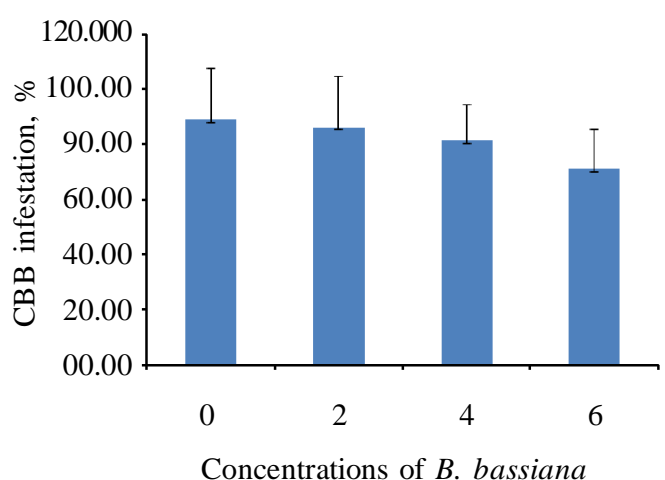

$(\mathrm{g} / 10 \mathrm{~L})$

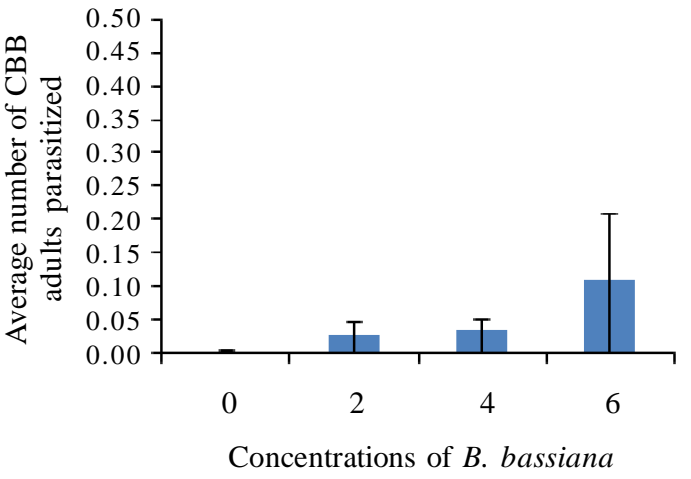

$(\mathrm{g} / 10 \mathrm{~L})$

Figure 4. Percentage of CBB infestation and CBB adult parasitized by B. bassiana on various concentration treatment of $B$. bassiana, four week after treatment 


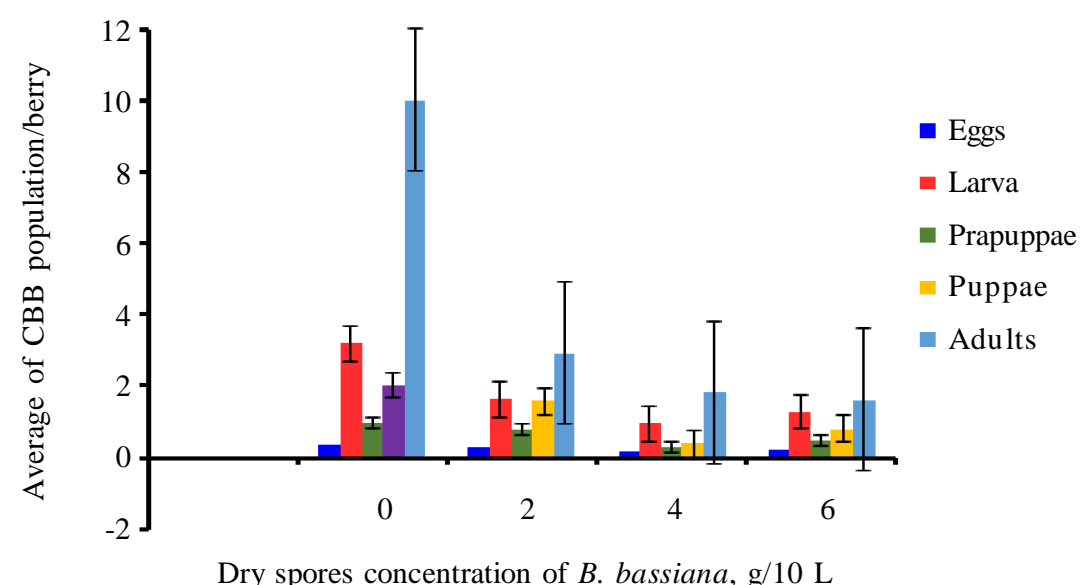

Figure 5. CBB population inside the coffee berry, four weeks after B. bassiana application

The observation on number of $\mathrm{CBB}$ adult infected by $B$. bassiana inside the berry, showed that B. bassiana in $6 \mathrm{~g} / 10 \mathrm{~L}$ indicated the highest percentage of CBB parasitized inside the berry was $0.1 \mathrm{CBB} /$ berry or $2.5 \%$ from total CBB population inside the berry. This indicated that increasing the concentration of B. bassiana, caused a decline in CBB attacks and found more CBB infected by $B$. bassiana. Application of B. bassiana in concentration 4-6 g dry spores/10 L showed the lowest of CBB population inside the berry. Based on this results, it was found that autodissemination of B. bassiana by $\mathrm{CBB}$ was low. The lowest of auto-dissemination process was presumably because the behavior of CBB infected by B. bassiana was dead at the entry hole of CBB in the discus of coffee berry.

An experimental auto-contamination trap was devised to infect Rhynchophorus ferrugineus (Olivier), the red palm weevil, adults with entomopathogenic fungi had been carried out to support integrated $R$. ferrugineus control programs (Francardi et al., 2013). In laboratory bioassays, the delivery system successfully attracted, infected and released weevil adults after they contacted cereal substrat inoculated with indigenous strains of Beauveria bassiana (BalsamoCrivelli) Vuillemin and Metarhizium anisopliae (Metchnikoff) Sorokin. Tests carried out with the experimental traps showed that $M$. anisopliae was the more virulent pathogen, causing $75 \%$ cumulative mortality in adults, while $B$. bassiana gave a $45 \%$ cumulative mortality. Infectivity of M. anisopliae was not affected by different cereal substrat, i.e. wheat and rice, since curculionid cumulative mortality $(95 \%)$ and treatment efficiency (95\%) were very high on both of them and red palm weevil LT50 was reached within the same time (15 days).

\section{B. bassiana Suspension Spray on CBB Adults}

B. bassiana has shown potensial as a commercial control agent and is registered for insects. Application of B. bassiana through autoinoculative means appears to be a more selective alternative and may be a preferable application strategy when nontarget beneficial insects are present in crops (Down \& Vega, 2003). 
Application of $B$. bassiana suspension directly on $\mathrm{CBB}$ adults showed that there was no significantly difference between the concentration treatment. Observation results four weeks after treatment showed that percentage of CBB infestation, number of CBB parasitized and population were lower than application of $B$. bassiana suspension on infected berries, because directly spraying on CBB adult caused a high mortality of CBB, so the CBB adults can not bore the coffee beries. In addition, it was likely not the case direct contact between insect CBB. Fungal dissemination within a host population occur due to activities and movements of the host; the fungus can exploit host behaviour like trophallaxis, tactile communication, grooming (in social insect) and mating to spread through a host population (Scholte et al., 2004).

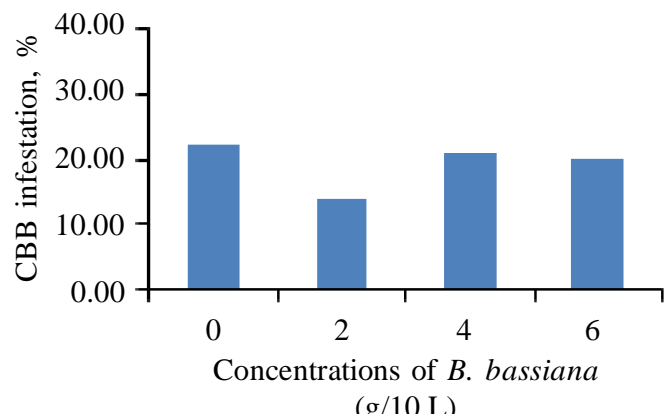

$(\mathrm{g} / 10 \mathrm{~L})$
A research by Monzón et al. (2007) reported the natural occurrence of the insect pathogenic fungus of B. bassiana in Hypothenemus hampei populations throughout the rainy season of 2004 (July-November) and 2005 (July-December). B. bassiana infections were found during most sampling dates in both years, on all three unsprayed coffee farms, the $B$. bassiana infection levels were higher in 2005 than in 2004 with mean prevalence of $12.1 \%$ and $2.7 \%$, respectively. No consistent density dependent correlation between $H$. hampei infestation level and B. bassiana infection level. This result showed that the percentage of naturally infection of $B$. bassiana on $H$. hampei in the field was lower. Therefore, to increase the role of $B$. bassiana in the integrated control of CBB, it needs to spray the suspension of $B$. bassiana, especially when CBB fly.

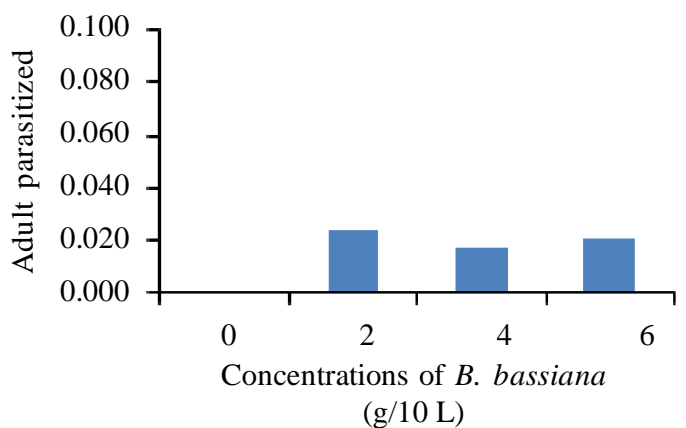

Figure 6. Percentage of CBB infestation and CBB adult's parasitized by B. bassiana on various spore concentration of B. bassiana, four week after treatment

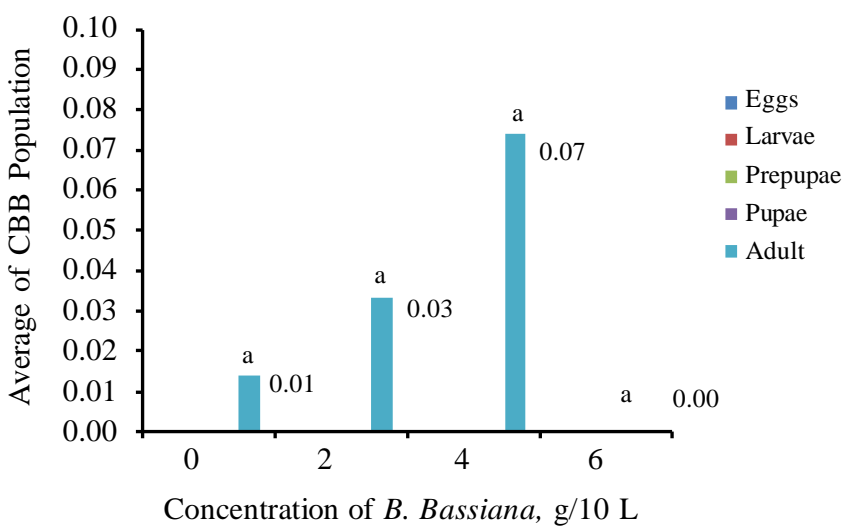

Figure 7. CBB population inside the coffee berry on various concentration of B. bassiana, four weeks after B. bassiana application 
The main methods employed for introduction of entomopathogens into the ecosystem were inundative and augmentative releases (Lacey \& Goettel cit. Maniania \& Ekesi, 2013). However, a new strategy is currently being considered, whereby insect pathogens are disseminated among target pest populations by using devices that attract insect pests into a focus of the pathogens (Vega et al., 2007). Maniania et al. (2006) demonstrated the prospects of using entomo-pathogenic fungus in contamination device $(\mathrm{Cd})$ for population suppression of tsetse by autodissemination of Metharizium anisopliae conidia. Dry conidia of $M$. anisopliae isolate ICIPE $30(1.5-2.0 \mathrm{~g} / \mathrm{Cd})$ were applied on the inner sides of the $\mathrm{Cd}$. The overall reduction in fly population relative to untreated control during the experimental period was $82.4 \%$ and $95.8 \%$ in Mfangano Island and Nzenze Island, respectively. The incidence of $M$. anisopliae in tsetse flies caught in fungus-treated island was generally low (35-46\%) during the first 12 weeks but increased between $48 \%$ and $83 \%$ afterward. Mycosis by $M$. anisopliae on tsetse flies could still be observed after two (30\%) and three $(9 \%)$ months following removal of the treatments. The persistence of the inoculum in the wild population could only be explained by horizontal transmission of the inoculum between flies, which is fundamental to the success of auto-dissemination approach.

\section{CONCLUSSIONS}

The adults of coffee berry borer can dessiminate the spores of $B$. bassiana by themselves. Percentage of parasitized CBB from total $\mathrm{CBB}$ population inside the berry was very low, just $2.5 \%$, therefore $B$. bassiana was not effective in suppressing CBB infestation only by auto-dissemination. To improve the effectiveness of $B$. bassiana for controlling CBB, it was advised to re-spray at least three times in every cropping season, especially at the flying time of CBB around 2 P.M.

\section{ACKNOWLEDGEMENT}

The authors sincerelly thank Director of ICCRI for his permision; USAID for funding this research through Clemson University and Virginia Tech; and many thanks to all technicians in Plant Protection Department of ICCRI who had participated in this research.

\section{REFERENCES}

Avery, P.B.; W. Ayne; B.H. Unter; G.H. David; All; M.A.J. Ackson; H. A. Powell \& M.E. Rogers (2009). Diaphorina citri (Hemiptera: Psyllidae) infection and dissemination of the entomopathogenic fungus Isaria fumosorosea (Hypocreales: Ordycipitaceae) under laboratory conditions. Florida Entomologist, 92, 608-618.

Ceja-Navarro, J.A; F.E. Vega; U. Karaoz; Z. Hao; S. Jenkins; H.C. Lim; P. Kosina; F. Infante; T.R. Northen \& E.L. Brodie (2015). Gut microbiota mediate caffeine detoxification in the primary insect pest of coffee. Nature Communications, 6, 1-9.

Cramer, P.J.S. (1957). Review Literature of Coffee Research in Indonesia. InterAmerican Institute of Agricultural Sciences. Turrialba. Costa Rica.

Dowd, P.F. \& F.E. Vega (2003). Autodissemination of Beauveria bassiana by ap beettles (Coleoptera: Nitidulidae) to overwintering sites. Biocontrol Science and Technology, 13, 65-75.

El-Sufty, R.; S. Al Bgham; S. Al-Awash; A. Shahdad \& A. Al Bathra (2011). A trap for autodissemination of the entomopathogenic fungus Beauveria bassiana by red palm weevil adults in date palm plantations. Egyptian Journal of Biological Pest Control, 21, 271-276.

Francardi, V.; C. Benvenuti; G. Barzanti \& P.F. Roversi (2013). Autocontamination trap with entomopathogenic fungi: a possible strategy in the control of 
Rhynchophorus ferrugineus (Olivier) (Coleoptera Curculionidae). Redia, 96, 57-67.

Junianto, Y.D. \& E. Sulistyowati (1994). Virulence of several Beauveria bassiana (Bals.) Vuill. isolates on coffee berry borer (Hypothenemus hampei Ferr.) under various relative humidities. Pelita Perkebunan, 10, 81-86.

Le Pelley (1968). Pests of Coffee. Tropical Sciences Series Longmans.

Maniania, N.K. \& S. Ekesi (2013). The use of entomopathogenic fungi in the control of tsetse flies. Journal of Invertebrate Pathology, 112, 83-88.

Monzón A.J.; F. Guharay \& I. Klingen (2007). Natural occurrence of Beauveria bassiana in, Hypothenemus hampei (Coleoptera: Curculionidae) populations in unsprayed coffee fields. Jurnal of Invertebrate Pathology, 97, 134-141.

Oliveira, C.M; A.M. Auad; S.M. Mendes \& M.R. Frizzas (2013). Economic impact of exotic insect pests in Brazilian agriculture. Journal of Applied Entomology, 137, 1-15.

Rashki, M. \& A. Shirvani (2013). The effect of entomopathogenic fungus, Beauveria bassiana on life table parameters and behavioural response of Aphis gossypii. Bulletin of Insectology, 66, 85-91.
Sulistyowati, E. (1991). Hama Utama Tanaman Kopi dan Cara Pengendaliannya. Bahan Pelatihan Teknis Budidaya dan Pengolahan Kopi. Jember, 23 September -5 Oktober 1991.

Sulistyowati, E.; Supandi; M. Shepard; M. Hammig \& G. Carner (2014). Integrated control of coffee berry borer, Hypothenemus hampei using Beauveria bassiana and attractant in Pakpak Bharat North Sumatera. Indonesian International Coffee Symposium (IICS). Banda Aceh, 18-20 November 2014.

Scholte, E.; B.G. Knols \& W. Takken (2004). Autodissemination of the entomopathogenic fungus Metarhizium anisopliae amongst adults of the malaria vector Anopheles gambiae s.s. Malaria Journal, 45, 1-6.

Vega, F.E.; P. Benavides; J.A. Suart \& S.L. O'neill (2002). Wolbachia infection in the coffee berry borer (Coleoptera, Scolytidae). Annals of the Entomological Society of America, 95, 374-378.

Vega, F.E.; P.F. Dowd; L.A. Lacey; J.K. Pell; D.M. Jackson \& M.G. Klein (2007). Dissemination of beneficial microbial agents by insects. p. 127-146. In: Lacey, L.A. \& Kaya, H.K. (Eds.), Field Manual of Techniques in Invertebrate Pathology. Second ed. Springer, Dordrecht. The Netherlands.

$* * 0 * *$ 